\title{
A Brief Historical Survey of Transplantations (From The Origins to the First Decades of the 20th Century)
}

Received: May 10, 2017; Accepted: May 22, 2017; Published: May 30, 2017

\section{Introduction}

"Those diseases that medicines do not cure are cured by the knife. Those that the knife does not cure are cured by fire. Those that fire does not cure must be considered incurable". One may read these words in Aphorisms, VII, $82^{1}$ of the so-called "Corpus Hippocraticum". Be or be not Hippocrates (c.469-c.399 B.C.) himself the author ${ }^{2}$ there is no difference: the few lines ( 3 in the Greek text!) witness that in the most ancient Greek medicine - and mainly in the field of medical deontology ${ }^{3}$ - surgery performed either with the knife, or with the cautery was nothing else than a therapeutic means, which the physician had recourse to whenever diet and medicines failed. Even if one may find some treatises on surgery, which show an exceptional skilfulness", this does not absolutely mean that the "iatrós" - i.e., the real "physician" - himself performed surgeries.

\section{Dealing with "Transplantations" - We Cannot Avoid Dealing Also with "Plastic" and "Aesthetic Surgery"}

When one applies now-a-days to a "surgeon" he turns first of all to a "Medicine and Surgery graduated"; second to a physician, who has followed a postgraduate course - generally lasting five years - of "specialization" and practises a particular and specific profession, that is to say that he is either a "heart surgeon" or a "nephrologist", and so on. And just for this "specialization" enjoys a particular prestige and an exceptional esteem, sometimes a real veneration. However the situation was quite different not only in the ancient Greek and Roman culture and society, but also during the whole Middle Age and all the subsequent centuries till a least the $18^{\text {th }}$ century.

Indeed what does it literally mean the Latin word "chirurgus" (read "kirùrgus"), the term our "surgeon" derives from?

${ }^{1}$ Cf. Hippocrates with an English translation, by W.H.S. Jones, London, William Heinemann LTD / Cambridge, Massachusetts, Harvard University Press, 1960, IV, p215.

${ }^{2}$ As a matter of fact none of the books of the Corpus Hippocraticum may be surely ascribed to Hippocrates himself, who runs the risk of remaining an "Author without works"!

${ }^{3}$ Suffice it to remember the Hippocratic Oath that is still a marvellous and fundamental document of medical deontology.

${ }^{4} \mathrm{As}$, for instance, in the case of the treatise "On the wounds of the skull".
Musitelli $\mathbf{S}^{1 *}$ and Oddenino $\mathbf{R}^{2}$

1 Expert of the History Office of the E.A.U. European Association of Urology, 2080, Zibido San Giacomo (Mi), S.S. dei Giovi n. 69 , Italy

2 Department of Plastic and Aesthetic Surgery, President of the ASSECE, European Association of Aesthetic Surgery, Cambridge, UK

*Corresponding author: Musitelli S

Đ sergiomusitelli@libero.it

Expert of the History Office of the E.A.U. European Association of Urology, 2080 Zibido San Giacomo (Mi), S.S. dei Giovi n. 69 - Italy.

Tel: 39- 029053748

Citation: Musitelli S, Oddenino R (2017) A Brief Historical Survey of Transplantations (From The Origins to the First Decades of the 20th Century). Ann Clin Lab Res. Vol. 5 No. 2: 174.

Moreover, what does it mean "chïrurgĭa" (read "kirùrgia")? The two terms are calques of the Greek "kheirourgós" (read "keirurgós") and "kheirourgía" (read "keirurgía") respectively and mean "hand labourer" and "handicraft". Therefore there was such a great difference between the "physician" and the "surgeon" that Aulus Cornelius Celsus ( $1^{\text {st }}$ century B.C. to $1^{\text {st }}$ century) - who is considered as the "Cicero of Medicine" for is splendid style - in the Prologue of his treatise "De Medicina" takes care to state that at Hippocrates' and his successors' times "the Art of Medicine was divided into three parts: one being that which cures through diet, another through medicaments, and the third by the hand", and specifies that "the Greeks call "dietetic" the first; "pharmaceutics" the second and "surgery" the third". However he forgets dealing with an at least brief summary of the History of Surgery and confines himself to an otherwise very interesting picture of Medicine in general. He will only remember - as we will point out afterwards - to give it to the reader in the briefest "Introduction" to the $7^{\text {th }}$ book of the treatise.

Moreover, starting from the first decades of the $3^{\text {rd }}$ century, and chiefly from the foundation of the great "Museum" - i.e., "the 
house of the Muses" - in Alexandria, which we could call "The first state University" created by the king of Egypt Ptolemy I Soter (c.367/366-283/282 B.C.) in the last years of his reign, from the one hand there was and exceptional improvement of the studies of Anatomy and, by consequence, a no lesser improvement of Surgery; from the other hand a nearly relentless debate was opened about the real nature of Medicine: is it a pure and simple "tékhne", i.e., an "Art" in the sense of "handicraft", or a real "epistēme", i.e., a real "Science"? In spite of Galen's (c.119-c.199 A.D) attempt at proving ${ }^{6}$ that Medicine is a real Science, the debate went on till the $14^{\text {th }}$ century - i.e., first in the Hellenistic, then in the Byzantine areas - although the "surgeons" - by then confined in the "limbo" of "labourers" - or, if one prefers, of pure and simple "handicraftsmen" when not accused of being either old-hands, or even "charlatans" - never took part to this debate, went their way and reached really exceptional goals between the $1^{\text {st }}$ and the $2^{\text {nd }}$ century with Antyllus and Heliodorus.

As for the "physicians" and their students they began fighting starting from the $14^{\text {th }}$ century and often even with bloody battles in the Western Europe, but mainly in Italy - in order to obtain that their "Art" enjoyed the rank of "faculty", and the battle lasted for nearly one century. Indeed the "Medical Schools" succeeded in obtaining to be officially recognized as something like a detached faculty of the most renowned Universities (Bologna, Padua, Pavia, Paris, etc.) - that were faculties of Theology and Jurisprudence only around the end of the $14^{\text {th }}$ century.

And the Surgeons? After the creation of the first "Faculties of Medicine" and the first scientific "Academies"7, they too entered a relentless conflict against the "Physicians" and only reached their goal in the $18^{\text {th }}$ century, when François Gigot de la Peyronie (1678-1747) ${ }^{8}$ not only succeeded in obtaining an official "Chair of Anatomy and Surgery", but even in founding the "Académie Royale de Chirurgie" and receiving a Royal Decree, which equalized it to the "Faculty of Medicine" of the Sorbonne University. At last the "Handicraftsmen" were officially promoted to the rank of "Surgeons" in the modern sense of the word.

However they did not yet enjoy an easy life, even after such an important goal. Indeed they were forced to struggle against the raging of the so-called "barber-surgeons", who, in spite of being generally rather ignorant of human anatomy, nonetheless had, so to say, "specialized" in performing often successful surgeries in cases of inguinoscrotal hernias, of extraction of bladder stones by perineal incision, of extraction of teeth, of amputation of sphacelated legs and even of breaking-down of the crystalline lens in cases of cataract ${ }^{9}$.

${ }^{5}$ "Arts" during the Middle Ages and the subsequent centuries till the $18^{\text {th }}$ century were something like our "corporations".

${ }^{6} \mathrm{Cf}$. his exceptionally elaborated booklet "The best physician is also a philosopher".

${ }^{7}$ In Paris, London and Berlin (all created in the $17^{\text {th }}$ and the following centuries and modelled on the first and glorious, "Accademia dei Lincei" founded by Federico Cesi (1585-1630) (abolished in 1936 and reconstituted in 1944), and the glorious but ephemeral (1657-1667) “Accademia del Cimento” founded by Galileo Galilei's (15641642) disciples.

${ }^{8}$ With the collaboration of Georges Mareschal (1658-1736).

${ }^{9}$ They penetrated through the cornea either with a subtlest needle (generally made of
At this point, we must clarify the concept of "specialization". When Herodotus (484-428 B.C.) in his "History" (II, 84) maintains that in Egypt "Medicine is divided as follows: each physician is physician for only one and not for many diseases and the whole region is full of physicians: some are physicians of the eyes, some others of the head, others of the teeth others of the belly and others of the shadowy diseases" we must not suppose that he is dealing with "specializations" in the modern sense of the word ${ }^{10}$. This alleged "specialization" is nothing else than that of the primitive "rain-"or "wind-" or "hunting-wizard" (or "-shaman" or "-sorcerer") that have absolutely nothing in common with our "specializations". Suffice it observing that the alleged exceptional anatomical knowledge of the Egyptian physicians relied on a complete ignorance of the anatomophysiology of the human body ${ }^{11}$ and even the alleged and most renowned anatomical knowledge of the otherwise very skilful embalmers was absolutely lesser than that of the cooks, who were perfectly aware that - for instance - kidneys could neither be cooked, nor be eaten without having been washed as carefully as possible in advance, in order to eliminate the terrible stench of urine. This being the fact, we must conclude that they knew perfectly that urine did not form into the bowels - as maintained by both the physicians and the embalmers - but into the kidneys!

Moreover the major part - not to say all - of the descriptions of a lot of different "surgeries" one can find in the medical papyruses ${ }^{12}$ concerns not only the treatment of bone fractures by dressings, seldom by splinting the fractured limb and generally accompanied by "spells", but also the reduction of dislocated joints and the cure of wounds by plasters and magic. These being the facts, the ancient Egyptian aesthetic "surgeons", or better "handicrafts", were mainly and nearly only from the one hand those who prepared not only the mixes for the make-up of both males and women of the upper classes; from the other hand the makers of exceptionally complex beards for the men and as well exceptionally complex periwigs for the women, let alone the ornaments that contributed to the realization of the "aesthetical beauty" of a person according with the concepts of "beauty" and "charm" of their times and culture.

But it is not enough: the Egyptian "Aesthetic Surgeons" took care of lengthening the skull - mainly of the descendants of royal extraction - by tight dressings around the skull of a newborn baby in order to create those men that Hippocrates calls "Longheads", the particular surgical procedure which the Egyptian had recourse to he describes as follows"13: "The races that differ but little from one another I will omit, and describe the condition only of those which differ greatly, whether it be trough

boxwood) or with a subtlest lancet, and rolled it between the cornea and the crystalline lens. This done, they supposed having eliminated the pathological membrane whilst they had eliminated just the crystalline lens!

${ }^{10}$ It would be really impossible for us to understand which kind of "specialization" could ever be that of the "physician", who is called "Guardian of the Royal anus" in the Egyptian medical papyruses

${ }^{11} \mathrm{All}$ the hieroglyphics representing the inner parts of a living body do not concern the human bodies, but animals' ones!

${ }^{12}$ Cf. mainly the "Ebers" the "Edwin-Smith", the "Hearst" medical papyruses:

${ }^{13} \mathrm{Cf}$. "Airs Waters and Places", XIV. 
nature or through custom. I will begin with the "Longheads". There is no other race at all with heads like theirs. Originally custom was chiefly responsible for the length of the head, but now custom is reinforced by nature. Those that have the longest heads they consider the noblest, and heir custom is as follows. As soon as a child is born they remodel his head with their hands, while it is still soft and the body tender, and force it o increase in length by applying bandages and suitable appliances, which spoil the roundness of the head and increase its length. Custom originally so acted that through force such a nature came into being; but as time went on the process became natural, so that custom no longer exercised compulsion. For the sperm comes from all parts of the body, healthy sperm from healthy parts, and diseased sperm from diseased parts. If, therefore, bald parents have for the most part bald children, grey-eyed parents grey-eyed children, squinting parents squinting children, and so on with other physical peculiarities, what prevents a long-headed parent from having a long-headed child $?^{\prime 14},{ }^{15}$. Apart from Hippocrates' mistake concerning the "acquired characteristics", this is the most ancient description if not of "aesthetic surgery" at least of "aesthetic handicraft" (Figures 1 and 2).

As for "aesthetic dentistry" - a field in which the Etruscan excelled - suffice it quoting two "Epigrams"16 of the Roman poet Martial (c.40-c.104 A.D.) The first reads as follows: "Thais has black teeth, Lecania has white teeth. Why? Simple! Thais has her own, Lecania has bought ones!". The second reads as follows: "Oh Lelia - the poet writes - you bear bought hairs and teeth and do not feel shame. But what shall you do for your eye? No artificial eyes exist!". As a matter of fact artificial eyes will be devised and described only more than 15 centuries later by Ambroise Paré (c.1517-1590) and, even better, by Hieronymus Fabricius of Acquapndente (1533-161917. Moreover a passage of Pliny the Elder's (23-79 A.D.) "Natural History"18 informs us tat the Roman hero Marcus Sergius - ancestor of the notorious Lucius Sergius Catilina ( $1^{\text {st }}$ century B.C.) - "had his right hand maimed during his first campaign" Nonetheless "he fought four battles using only his left hand". However he "provided himself with an iron right hand and after having fixed it firmly to the stump he succeeded in breaking the siege of Cremona, saved Piacenza and seized twenty enemy camps in Gaul". Also the Roman "aesthetic handicrafts" had made their work very skilfully, although Pliny does not inform us about the real form and the real mechanism of this exceptional artificial limb.

As for the ancient Persia, no "Scientific Literature" exists. We are only informed about a sort of "cosmetic handicraft" by a really interesting and really amusing episode of Xenophon's

\footnotetext{
${ }^{14} \mathrm{By}$ contrast modern biologists hold that acquired characteristics are not inherited!
}

${ }^{15}$ The purpose of the described deformation was dual: from the one hand it was the aesthetic characteristic of high-class people; from the other hand it had the practical aim of letting one bear on his head the often biggest mitres (Figure 1) and even the "double crown" (Figure 2), the "White" (the inner, corresponding to the "Higher Egypt") and the "Red" (the outer, corresponding to the "Lower Egypt").

${ }^{16} \mathrm{Cf}$. V, 43 and XII, 23 respectively.

${ }^{17}$ Both Paré and Acquapendente never dealt with "plastic" and "aesthetic surgery" but confined themselves to devising, describing and illustrating - most probably having also recourse to - artificial prostheses.

${ }^{18} \mathrm{Cf}$. VII, 28, 104
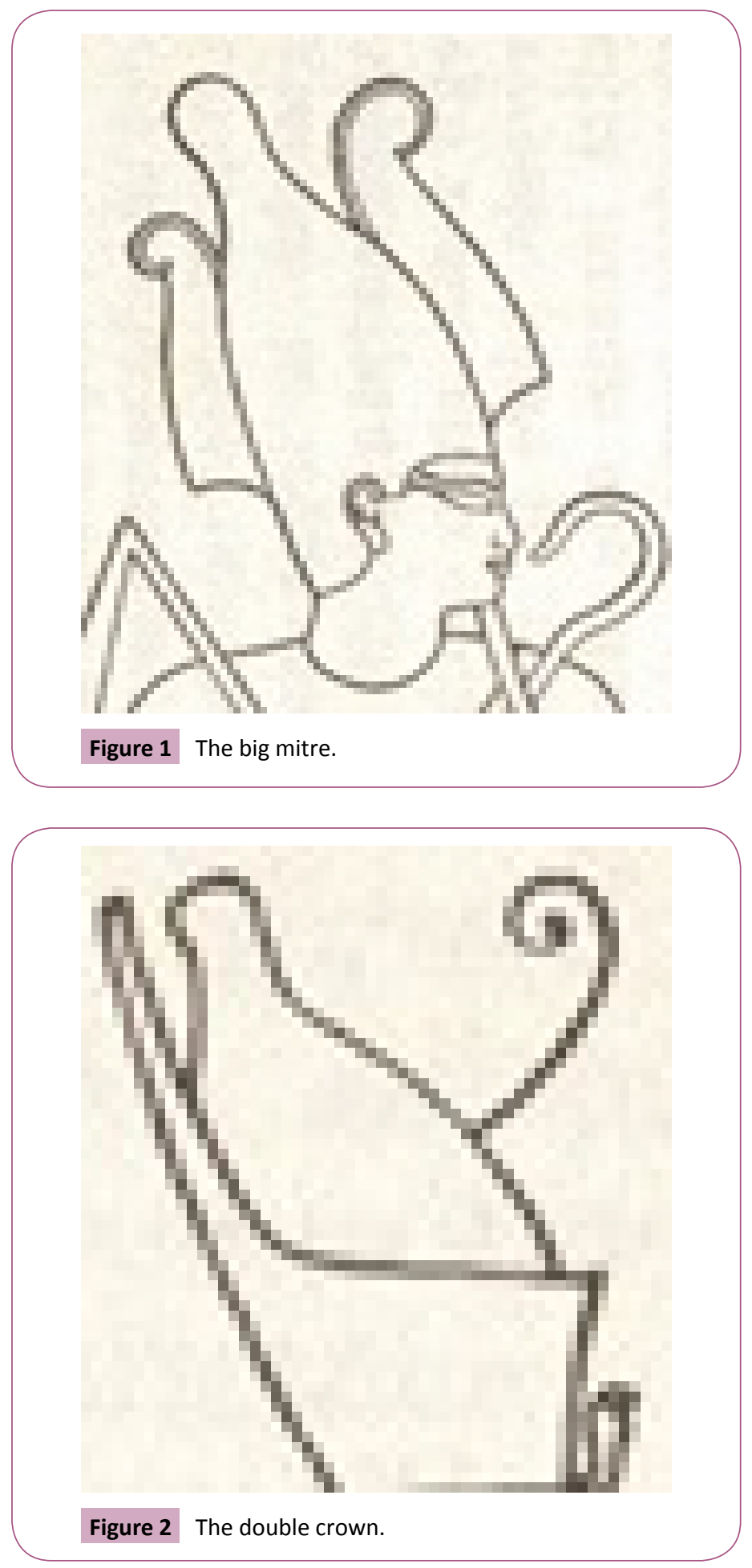

(c.430-c.354 B.C.) Cyropaedia"19. The Greek author informs us that Astyages (the King of the Medians) asked his daughter Mandane, Cyrus' mother, to bring his still baby nephew to him, because he had been informed that he was provided with exceptional qualities. Mandane obeyed and Cyrus, after having embraced his grandfather affectionately, ${ }^{20}$ : "Seeing him completely adorned, with made-up eyes by black edgings and his orbits coloured with eye-shadow, wearing a wig... and bearing a purple mantel,

${ }^{19} \mathrm{An}$ idealized biography of Cyrus the Elder, the founder of the Persian Empire.

${ }^{20} \mathrm{Cf}$. Cyropaedia I, 3. 
white surcoats, twisted necklaces and bracelets, hence seeing all such his grandfather's ornaments, Cyrus, devouring him with his eyes, exclaimed: "Mammy, how beautiful my grandfather is!". The Medic "aesthetic handicrafts" had clearly made a work that was at least as excellent as that made during a lot of centuries by their Egyptian colleagues!

However everyone may conclude that none of the quoted passages deals with any kind of "transplantation" or of "aesthetic surgery" in the real sense of the term - perhaps Hippocrates' "Long heads" excluded at least in part - and only allude either to more or less suitable artificial prostheses ${ }^{21}$ or to different kinds of maquillage. Moreover it is worth emphasizing that the same picture and the same conclusion may be referred to the ancient Assyrian and Babylonian, as well as to the ancient Persian medical treatises and to those of the Latin and Byzantine authors from Celsus to the whole Middle Ages. Indeed the many thousands of Assyrian and Babylonian tablets we have discovered inform us that from the one hand there were "physicians", i.e., the socalled "bâru"22, the "âshipu"23 and the "âsû", who was the real "physician"; from the other hand there was he "gallabu", who was the "barber surgeon", who performed extractions of teeth, markings and often even castrations of slaves and other manual works typical of the "barbers". A for the rest, they also realized like their Egyptian colleagues - not only complicated beards and wigs for high rank peoples, but also cosmetics, toothpastes and gargles ${ }^{24}$.

At this point we can pass to dealing with real "grafting" and real "transplantations", which all the preceding millennia and the preceding centuries absolutely ignored, as we have emphasized above. As a matter of fact they began being performed only in Greece and Rome. Although the ancient Greeks and Romans confined themselves to performing successfully only graftings of fruit plants we must deal with this argument because - as we will point out later - the Greek and Latin techniques inspired Gaspare Tagliacozzi during 1545-1599 - the founder of modern "aesthetic surgery" - as he himself maintains. Pliny the Elder's (20-79 A.D) most important passage concerning grafting ${ }^{25}$ (cf. Natural History XV, 17 ff.) reads as follows "This department of life has long ago arrived at its highest point, mankind having explored every possibility, inasmuch as Virgil (cf. Georgics, II, 69 $\mathrm{ff}.)^{26}$ speaks of grafting nuts onto an arbutus, apples on a plan and cherries on an elm. And nothing further can be devised - at all events it is now a long time since any new kind of fruit has been discovered" although he maintains that "religious scruples do not permit us to cross all varieties by grafting". However it is worth observing that Pliny the Elder derives from both Marcus Porcius Cato (234-149 B.C.) and Marcus Terentius Varro (116- 27

${ }^{21}$ The Etruscan handicrafts were real masters in realizing dentures and dental bridges ${ }^{22} \mathrm{~A}$ term we could translate "diviner"

${ }^{23} \mathrm{~A}$ term we could translate either "exorcist" or "charmer"

${ }^{24}$ They had not toothbrushes and used their fingers!

${ }^{25}$ (cf. Natural History XV, 17 ff.)

${ }^{26}$ Virgil's passage reads as follows: "We graft the shoots of a walnut cutting into a rough strawberry- tree, and the sterile planes produce marvellous apples, beach-trees bear chestnuts, the white flowers of a pear-tree whiten the branches of a wild ash and pigs graze under helms".
B.C.). He surely also knew Lucius Iunius Moderatus Colummella's (4-70 E.V.) De re rustica (On agriculture), which he quotes in a lot of passages. However none of these passages concerns grafting, a topic which - on the contrary - Columella deals with at length in the $4^{\text {th }}$ book (chapter XXIX ff.) of his marvellous treatise.

The most important passage of Cato's De agri cultura (On agriculture, $\mathrm{XL}, 2 \mathrm{ff}$.) reads as follows: "Figs, olives, apples, pears and vines should be grafted in the dark of the moon, after noon, when the south wind is not blowing. The following is a good method of grating olives, figs, pears and apples: cut the end of the branch you are going to graft, slope it a bit so that the water will run off and in cutting be careful not to tear the bark. Get you a hard stick and sharpen the end, and split a Greek willow. Mix clay or chalk, a little sand, and cattle dung, and knead them thoroughly so as to make a very sticky mass. Take your split willow and tie it around the cut branch to keep the bark from splitting. When you have done this, drive the sharpened stick between the bark and the wood two fingers-tips deep. Then take your shoot, whatever variety you wish to graft, and sharpen the end obliquely for a distance of two finger-tips; take out the dry stick, which you have driven in and drive in the shoot you wish to graft. Fit bark to bark, and drive it into the end of the slope. In the same way you may graft a second, a third, a fourth shoot, as many varieties as you please". In the following chapters (XLI and XLII) Cato deals at length with "vine, fig and olive grafting", but the suggested methods are nearly the same.

As for Varro's Rerum rusticarum libri tres (Three Books on agriculture) suffice it quoting one only passage (I, XL, 6): "No matter how good the pear shoot which you graft onto a wild pear, the fruit will not be as well flavoured as if you graft it onto a cultivated pear. It is a general rule in grafting, if the shoot and the tree are of the same species, as, for instance, if both are of the apple family that for the effect on the fruit the grafting should be of such a nature that the shoot is of a better type than the tree on which it is grafted". Although Columella ${ }^{27}$ deals at exceptional length with grafting of nearly all kinds of fruit trees, nonetheless he does not add anything more or anything different from Cato's and Varro's statements The only exceptions are the length of the treatment of the single topics and their nearly numberless graphic details.

In spite of the ponderous medical treatises of the Byzantine Oribasius (325-403 A.D.) and Psellus (1018-1096), one would look in vain for even the faintest allusion to "Aesthetic", let alone "Transplantation Surgery". In fact, the only contributions of the Byzantine physicians concern "Uroscopy", a topic, which both Theophilus Protospatarius ${ }^{28}$ (c.600-c.650 A.D.) and John Actuarius $^{29}$ (flourished in the first half of the $14^{\text {th }}$ century) dealt with, writing - to tell the truth - nothing else than a lot of

${ }^{27}$ Both Cato and Varro and even, Columella derive their treatments of "grafting" mainly from personal experience but not in minor part from chapter 6 of the $4^{\text {th }}$ book of the great treatise "Aetiology of plants" of the Greek Theofrastus (372/369288/285 A.C.)

${ }^{28}$ i.e., "Colonel of the Imperial guard". His treatise "De urinis" (On urines) consists of 23 chapters

${ }^{29}$ i.e., "Imperial physician". His monumental treatise "De urinis" consists of 7 books! 
ungrounded nonsense, although their nearly absurd works gave origin to the really hackneyed series of treatises "De urinis" that literally spread throughout the whole European Middle Ages.

As for Psellus' poem "On Medicine" 30 it doesn't tell us anything new and has probably the only merit of having been the model - through the Salernitan archbishop Alphanus (c.105-1085), who made Psellus' acquaintance during his stay in Byzantium - for the unworthily famous "Regimen sanitatis Salernitanum", which like the treatises "De urinis" - is nothing but a verbose raving of pitiful and absolutely absurd and ungrounded nonsense.

If the Byzantine treatises are really squalid under the point of view of surgery in general and of transplantation and aesthetic surgery in particular, the treatises of the Arab authors are no less disappointing. We are not only alluding to Ibn Sinā (the Latin Avicenna) (980-1037), who - to tell the truth-never made himself out to be a surgeon - but also and most of all to his predecessors and successors, who enjoyed the fame of being outstanding masters according to all the Medieval physicians. Should one read the often weighty treatises of Abū-Bakr Muhammad ibn Zakaryyā ar-Rāzi (Latinized into Rhazes / Rasis) (c.860-c.923), of 'Alī ibn al-'Abbās al-Māgūsī (Latinized into Haly/Hali/Aly/ Ali Abbas) (930-994) (whose "Royal book" was translated and passed off as his own work by Constantine the African (c. 10151087) - considered as a great master of the Salernitan School with the presumptuous title "Pantegni" (Complete Art); of Abū 'I Qāsim az-Zahrāwī Kalaf ibn 'Abbas (the Albucasis/Abulcasis of the Medieval authors) (936-1010/1013); of Abū Marawān 'Abd 'I-Malik ibn Abū 'I-'Alā ibn Zuhr (Latinized into Avenzoar) and of Abū 'I Walīd Muhammad ibn Ahmad ibn Muhammad ibn Rušd (Averroes/Averrois, and still nowadays Averroes!) during 11261198 , would look in vain for original pages concerning general surgery, let alone "aesthetic" or "transplantation surgery", in few words nothing at all that we do not already know from Celsus, Heliodorus and Antyllus, with the addition of often colossal anatomical mistakes. However we must emphasize that none of these authors derived the matter directly from Celsus, but from the Greek treatises they had still at their disposal and that went generally lost ${ }^{31}$ in Europe.

Only the great Arab anatomist Abū 'I-Hasn 'Alī ibn al Hāzim ibn an-Nafiss al Quarišī (commonly abbreviated into "Ibn an-Nafis during 1210-1288, represents an astonishing exception: in his Šarh Tašrīh al-Qānūn (Commentary to the anatomy of Avicenna's "Canon") he peremptorily maintained - against all the former anatomists, starting from Galen - that that the interventricular septum is not pervious and that the venous blood passes from the right ventricle to the lungs and from the lungs to the left ventricle. Therefore he described perfectly the so-called "lesser circulation" only re-discovered by Realdo Colombo (c.1516-1559) three centuries later. However this fundamental discovery had not even the faintest influence on the future development of the Arab and European Medieval surgery, let alone on the history of "reconstructive" and "transplantation surgery".

${ }^{30}$ It consists of 1.373 iambics!

${ }^{31}$ Even Galen's Greek text of "Anatomical procedures" was only preserved till chapter 6 of the $9^{\text {th }}$ book and the rest till the end $f$ the $15^{\text {th }}$ book was only preserved in an Arab translation , moreover only discovered at the end of the $19^{\text {th }}$ century!
Moreover nobody may flatter himself on finding something more than some briefest allusion to a sort of "plastic surgery" in Cerrāiyyet'ül-Hāniyye (Imperial surgery") of Serafeddin Sabuncuoglu during 1385-1468 A.D. ${ }^{32}$, the author exceptionally praised by the Iranians as the founder of the Surgery School of the Ottoman empire. The whole treatise is nothing else than a real Anthology of passages of the surgical treatises of the previous Arab authors - mainly Albucasis - and contains very few statements that one may consider as original: 1) he considers cauterization to be a real panacea, which a surgeon must have recourse to even to cure headache, migraine, stroke, fatness, leprosy, gangrene, backache, liver diseases, dropsy and so on; 2) however one can also find some chapters that could be included - with a lot of goodwill - in the roll call of "unconscious plastic surgery", like those dealing with a series of different ugly affections mainly of the face: lachrymation, cataract, ozaena, malformations of the eyelids and the eyelashes, meybomian cysts, staphylomas, etc. Obviously Serafeddin from the one hand plunders the treatises of the previous Arab authors; from the other hand considers cauterization the real heal-all also for these cases.

At last we can begin dealing with the birth of the real modern "aesthetic" and "transplantation surgery", i.e., the fist attempts at transplantations in men. Some historians of Medicine maintain that the Sicilian Branca and Vianeo families (16 $6^{\text {th }}$ century) from Catania and Tropea respectively, after which city the technique was called "Magia tropaeensium" (Magic of the people of Tropea), derived their technique of reconstruction of noses from the Byzantine surgeons but it is a simple historical mistake ${ }^{33}$. In fact no passage concerning transplantations may be found in any of the Byzantine medical and surgical treatises, let alone in Oribasius. By contrast, the first description of the transplantation of a nose may be found in a letter sent by the poet Elisio Calenzio during 1430-1503, to one of his friends, a certain Orpianus, in $1452^{34}$. The letter reads as follows: "Orpianus, if you wish to have your nose restored, come here. Really it is the most extraordinary thing in the world. Branca of Sicily, a man of wonderful talent, has found out how to give a person a new nose, which either builds from the arm, or borrows from a slave. When I saw this, I decided to write to you, thinking that no information could be more valuable. Now if you come, I would have you know that you shall return home with as much nose as you please. Fly!".

Leonardo Fioravanti during 1518-1588 from Bologna (Figure 3), in his turn, stole the "secret" procedure from the Vianeo and began performing himself the reconstruction of noses by autograft.

Grabbing the chance of the amity between Bologna and Tropea, he reached the Vianeo's laboratory on the pretext of waiting for a

${ }^{32}$ The treatise was written in 1465 by the author at that time already 80 years old and consists of 3 books (or better "chapters") divided into 193 sections, is illustrated by a lot of rather naive figures and is preserved in 3 manuscripts, 2 of which ere probably written by the author himself, the third is a copy of one of them written in the $18^{\text {th }}$ century and preserved in the Bibliothèque Nazionale of Paris

${ }^{33}$ Cf. L. Belloni, Dalle "riproduzioni animali" di L. Spallanzani agli "Innesti animali" di Giuseppe Baronio, (From L. Spallanzani's "animal reproductions" to Joseph Baronio's "animal graftings") in Physis, Rivista di Storia della Scienza, Leo S. Olschi Editore, Firenze, Vol. III, Fasc. I, 1961, p. 1 ff.

${ }^{34} \mathrm{Cf}$. Epistolarum libri quinque (Five books of letters), III, n. 25. Cf. also W. J. Bishop, The early History of Surgery, Robert Hale Limited, London, 1960, p. 85. 
fellow-citizen, who needed the reconstruction of his nose. As luck would have it just in those days a patient occurred, who needed a new nose. Fioravanti, shamming to be looking elsewhere, observed carefully the whole stages of the surgical procedure with the tail of his eye and succeeded in stealing Vianeo's "secret", which he later described in chapter $47^{\text {th }}$ of the first book of his treatise "Il Tesoro della vita umana. Dell'Eccellente Dottore e Cavaliere Maestro Leonardo Fioravanti Bolognese. Diviso in libri quattro" (The Treasure of human life written by the Excellent Doctor, Knight and Master Leonardo Fioravanti from Bologna and divided into four books), printed in Venice in 1570 . The pertinent passage reads as follows: "shamming to be not able to observe such a thing, I turned my face backwards, but my eyes saw it very well, so that I succeeded in seeing perfectly the whole secret and learned it. The stages of the procedure were the following: fist of all they purged the patient, who wanted to undergo the surgery; then they seized the skin of his left arm between the shoulder and the elbow by tongs $\mathrm{s}^{35}$ and inserted a big lancet between the tongs and the muscle; at this point they inserted a strip of cloth and tended that skin until it became widest. When it was wide enough in their opinion, they scarified and trimmed the borders of the nose, cut the higher tip of the prepared skin, sewed it to the scarified nose and bound the patient so carefully and skilfully that he was absolutely prevented from moving until the above mentioned skin was completely joined with the nose. This done, they cut the other extremity of the skin, scarified the upper leap, sewed the above mentioned skin of the arm and tended it until it was perfectly joined with the lip. After having done this, they inserted a metal nose mould into which the new nose grew in correct proportion and became stable, although rather whiter than the face" (Figure 4).

Apart from the great surgeon Hieronymus Fabrizi (or Fabricius) of Acquapendente (1533-1619), the glory of the final foundation of the modern "plastic" and therefore "aesthetic surgery" in West Countries must be ascribed to Gaspare Tagliacozzi and to his two treatises "De curtorum chirurgia per insitionem" (On the surgical reconstruction of mutilated men by grafting) (printed in Venice in 1597) and the posthumous "Chirurgia nova" (New surgery) (printed in Frankfurt in 1598). We say "final foundation...in West Countries" for two reasons: 1) because "rhinoplasty" was successfully performed not only - as said above - in South Italy since the $15^{\text {th }}$ century ${ }^{36}$ but also - and even "since immemorial time", as we will emphasize later - in East India; 2) because he made a most serious attempt at giving his surgical technique a scientific fundament, although with a lot of naiveties and his steadfast "galenism" ${ }^{37}$, whilst the prior surgeons were real "empiricists", i.e., nothing more than "barber surgeons"38; 3) because he could not yet know the Indian technique that was surely easier than his own but was only known in Europe at the end of the $18^{\text {th }}$ century.

\footnotetext{
35 The later so-called "Taglicozzi's tongs" (Figure 4).

${ }^{36}$ As Tagliacozzi himself knew!

${ }^{37}$ To the point of claiming "I prefer to disapprove Vesalius rather than renounce defending Galen"!

${ }^{38}$ Obviously only Acquapendente excepted.
}

However Tagliacozzi's surgical procedure was not different from the Sicilian Branca's an Vianeo's one, as the most famous and significant figure among the nearly numberless of his treatise clearly proves (Figure 5).

In order to strengthen his theories he has recourse to quoting nearly numberless prior authors: Virgil, Pliny the Elder, Vitruvius ( $1^{\text {st }}$ to $2^{\text {nd }}$ century A.D.), St. Augustine (354-430 A.D.), Apuleius (c.120/123-c.200 A.D.), Aristotle (384-322 B.C.), Cicero (106-43 B.C.), Quintillian (c.35-c.97 A.D.), Celsus and Galen, Columella, and even the Bible! Although none of these quoted authors -

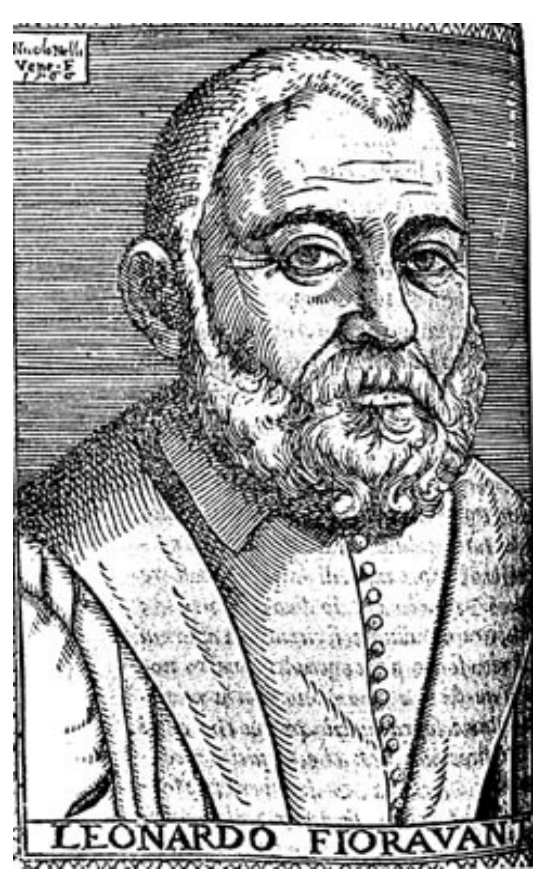

Figure 3 Leonardo Fioravanti's portrait.

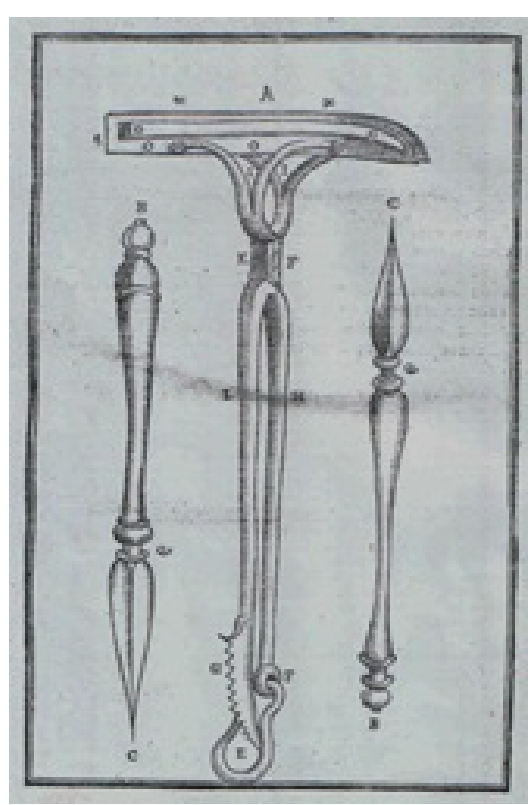

Figure 4 The so-called Taglicozzi's tongs 
obviously Celsus and Galen excepted - ever dealt with surgery, nonetheless they prove that Tagliacozzi was not at all a "barber surgeon" but a real and exceptionally learned scientist. At any rate it is worth emphasizing that he did not consider his "surgery" to be "aesthetic" but nothing else than what we could call "plastic and therapeutic surgery" the "aesthetical" results of which were nothing but "collateral effects". This means that he had not even the faintest idea of the really revolutionary consequences his work would cause in the following centuries on the History of Surgery in general and on the future exceptional improvements of "plastic and aesthetic surgery" in particular.

He clearly deals with "autografts". However one can also find an interesting and rather astonishing allusion to "homografts". After having observed that the different kinds of grafting could prove that it could not be impossible to graft onto a patient a flap of skin taken from another person, that this procedure would give the patient the advantage that the sufferer would be...another man $(!)^{39}$, and that it could be much more possible because the "nature" of all men is the same, whilst the "nature" of the different plants is not at all the same (the "nature" of a fig is quite different from that of an apple), nonetheless he concludes - in full accordance with Galen - that the different "temperaments" 40 of the men prevent the surgeon from having recourse to such a procedure.

As for the ancient Indian transplantation technique (i.e., the socalled "Mahratta's method"), it is quite similar to Tagliacozzi's one, but - apart from being exceptionally simpler and quicker at Tagliacozzi's time it went back more than at least twenty/thirty centuries before him, although he obviously could not know it, most of all because the surgical procedure of the Indian Mahratta - which was practiced "from immemorial time" - was only known in Europe in 1794 (Figure 6) thanks to a letter published in the journal "Gentlemen's Magazine".

The letter - sent by an unknown B. L to Mr. Urban - pseudonym of Edward Cave during 1691-1754, the founder of the Gentlemen's Magazine - reads as follows: "A friend has transmitted to me, from the East Indies, the following very curious, and in Europe, I believe, unknown chirurgical operation, which has long been practised in India with success: namely affixing a new nose on a man's face. The person represented in plate 1 is now in Bombay. Cowesjee, a Mahratta of the cast of husbandmen, was a bullock-driver with the English army in the war 1792, and was made a prisoner by Tippoo (1758-1799) ${ }^{41}$, who cut off his nose and one of his hands. In this state he joined the Bombay army near Seringanatam, and is now a pensioner of the honourable East India Company. For above 12 months he remained without a nose, when he had a new one put on by a man of the Brickmaker cast, near Poonah. This operation is not uncommon in India, and

${ }^{39} \mathrm{Cf}$. S. Musitelli, A Brief Historical Survey of Anaesthesia from Homer to the $19^{\text {th }}$ Century, in Research, $2014 ; 1.606$. There is a mistake in the title: $\left(9^{\text {th }}-8^{\text {th }}\right.$ century B.C.) instead of $\left(5^{\text {th }}-4^{\text {th }}\right.$ Century B.C. $)$ !

${ }^{40}$ According to Galen's "qualitative perception" of all the phenomena, the "temperament" was the "balance" of the 4 humours (blood, phlegm, black and yellow bile) and their qualities (hot, cold, moist and dry).

${ }^{41}$ Ruler of the Kingdom of Myhore. has been practised from time immemorial. Two of the medical gentlemen, Mr. Thomas Cruso and Mr. James Trindlay, of the Bombay presidency, have seen it performed, as follows: A thin plate of wax is fitted to the stump of the nose, so as to make a nose of a good appearance. It is then flattened, and laid on the forehead. A line is drawn around the wax, and the operator then dissects off as much skin as it covered, leaving undivided a small slip between the eyes. This slip preserves circulation till a union has taken place between the new and old parts. The cicatrix of the stump of the nose is next pared off, and immediately behind this raw part an incision is made through the skin, which passes around both "alae" and goes along the upper lip. The skin is now brought down from the forehead, and, being twisted half round, its edge is inserted into this incision, so that a nose is formed with a double hold above, and with the "alae" and "septum"

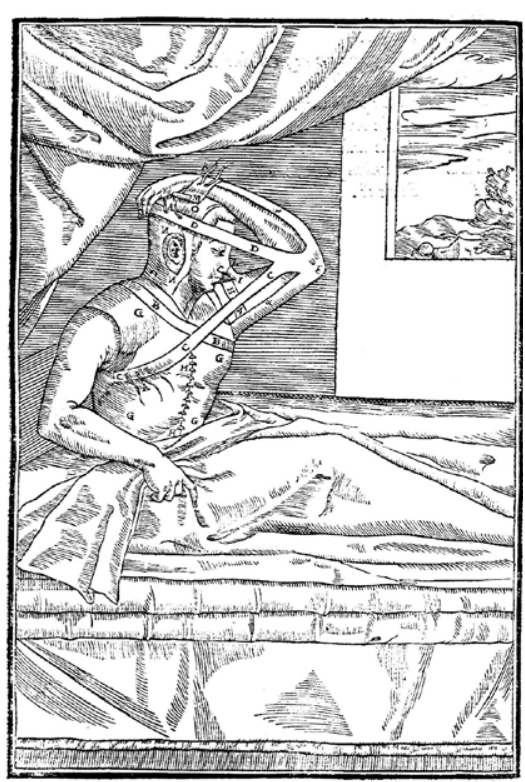

Figure 5 Tagliacozzi's patient immobilized in order to facilitate the take of the new nose.

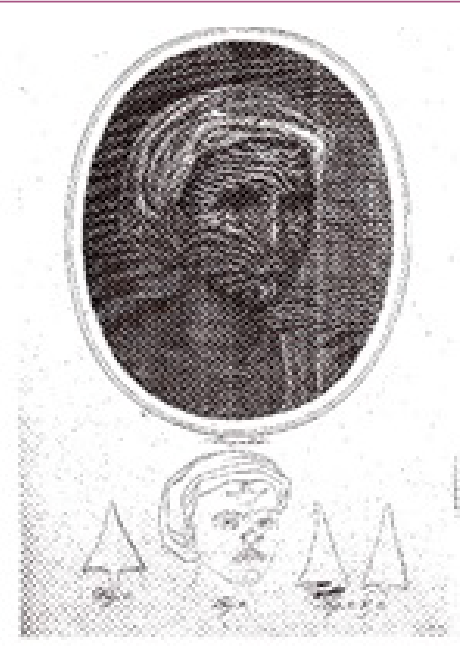

Figure 6 The engraved picture. 
below fixed in the incision. A little "Terra Japonica" is softened with water, and being spread on slips of cloth, five or six of these are placed over each other, to secure the joining. No other dressing but this cement is used for four days. It is then removed, and cloths dipped in "ghee" (a kind of butter) are applied. The connecting slips of skin are divided the $25^{\text {th }}$ day, when a little more dissection is necessary to improve the appearance of the new nose. For five or six days after the operation, the patient is made to lie on his back; and on the tenth day, bits of soft cloth are put into the nostrils, to keep them sufficiently open. This operation is very generally successful. The artificial nose is secure and looks nearly as well as the natural one; nor is the scar on the forehead very observable after a length of time. The picture from which this engraving is made was painted in January 1794 ten months after the operation.

As everyone can easily realize and we pointed out above, all the former surgeons - from the Branca and Vianeo families and Fioravanti to Tagliacozzi, as well as the Indian surgeons confined themselves to performing autografts. Apart Jacopus from Varagine's (now Varazze) (1228/30-1298) Legenda aurea (written either in 1255 or in 1266), in which the author describes the first legendary "heterograft" performed by the Saint physicians Cosmas and Damianus - martyred during the reign of the Emperor Diocletian (284-313) - in the parvis of the Basilica of Isernia in Italy, i.e., the transplantation of the leg of a dead Ethiopian onto a white man after having amputated his sphacelated left one (Figure 7), as this is only a legend, the real first attempts at homograft and heterograft in animals and men were performed by the great English surgeon John Hunter during 1728-1793, and by the Italian Giuseppe Baronio (c.1759-1811), both of whom we shall deal with later.

But let us deal with a particular chapter of the History of "plastic" and "transplantation surgery": the alleged "regeneration of eyes". Aristotle wrote in his great treatise "History of animals"42: "Someone maintain that also in snakes occurs what does in young swallows. Should one gouge the snake' eyes out, they affirm that they re-form" and adds ${ }^{43}$ that "also the tails of lizards and snakes, when cut out, re-form". However, after having repeated the same statement ${ }^{44}$ with reference to the "young swallows", he tries to explain the astonishing phenomenon and writes ${ }^{45}$ : "Should one gouge out the eyes of the young swallows as soon as they are born, they recover" because "he harms budding eyes, that $s$ to say not yet perfectly formed and therefore they re-form and develop again".

Pliny the Elder, in his turn", after having stated that "many animals have made discoveries destined to be useful for men as well" affirms that "Celandine was shown to be very healthy for the sight by swallows using it as a medicine for their chick's sore eyes". Pliny clearly derived this rather absurd statement

${ }^{42}$ Cf. 2, 17, 508b 4-7.

${ }^{43}$ Cf. ibid. 7-9.

${ }^{44}$ Cf. ibid. 6, 5, 563a, 14-16

${ }^{45} \mathrm{Cf}$. "Generation of animals", 4, 6, 774b 31, 1-4.

${ }^{46} \mathrm{Cf}$. "Natural history", VIII, 41, 97.

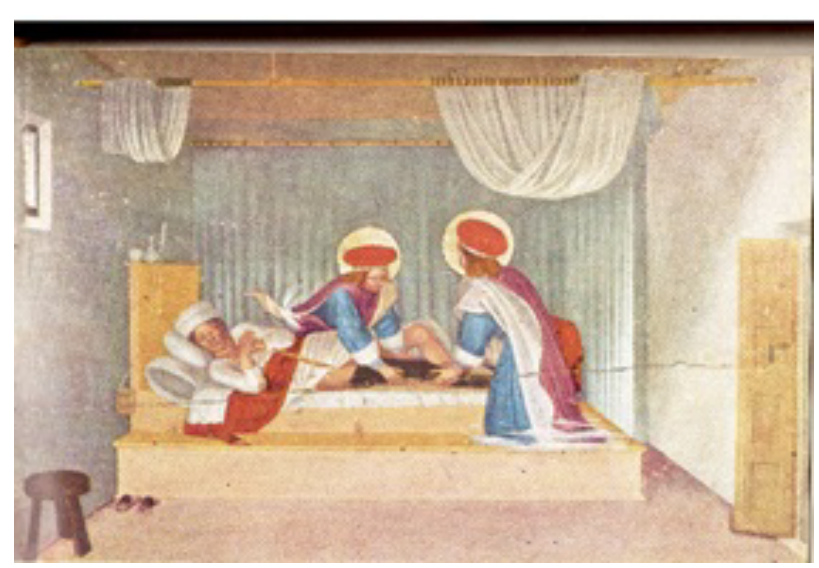

Figure 7 Legendary heterograft performed by the Saint physicians Cosmas and Damianus (Beato Angelico's (1387-1465) panel preserved in the San Marco Museum in Florence).

from Pedanius (or Pedacius) Dioscorides of Anazarba ( $1^{\text {st }}$ century A.D. $)^{47}$, whose words he quotes nearly word for word. Celsus too gives us the same statement ${ }^{48}$, although supposing that it is rather doubtful. However as a matter of fact, this absolutely groundless theory was repeated not only by St. Isidore of Seville $(c 570-636)^{49}$ but even by Benvenuto Cellini during $1500-1571^{50}$, i.e., about two millennia later!

However it is worth to observe that Pierandrea Mattioli during 1500-1577, subscribed to Celsus doubt in his Latin and commented translation of Dioscoides' "Medical matter" (printed in Venice in 1544). He denied the supposed miraculous virtues of celandine "because - he writes - neither Art, nor Medicine but nature itself performs all this".

In spite of the well grounded doubts of Celsus and Mattioli, the populace went on believing in celandine's miraculous virtues to the point that the great biologist Francesco Redi during 1626-1698 - a strongest supporter of the "Galilean scientific revolution" 51 , who demolished Aristotle's theory of "spontaneous generation" of insects - wrote in a passage of his "Letter to Father Athanasius Chircher during 1602-1680 of the Society of Jesus" entitled "Experiences about different natural things and in particular those that have been imported from the Indies" that those, who are still maintaining celandine's miraculous virtues are nothing else than "Western fanatic trickers" as he could conclude after having made a lot of experiments "on pigeons, on hens, gooses, ducks, pheasants" and having observed tat their pierced eyes "healed spontaneously in the space of 24 hours and

\footnotetext{
${ }^{47}$ Cf. "Medical matter", II, 180.

${ }^{48} \mathrm{Cf}$. "De Medicina", VI, 6, 39.

${ }^{49} \mathrm{Cf}$. "Etymologies", XVII, 9, 36.

${ }^{50} \mathrm{Cf}$. "Life". II, 72.
}

${ }^{51}$ Which started our modern "experimental scientific method", i.e., not simple "empiricism", but "experimentalism" that consists of tree stages: 1) observation of the "quantitative" and therefore "mathematical" characteristics" of a phenomenon; 2) formulation of a "rational and mathematical hypothesis"; 3) "experiment": 4) should the "experiment" confirm the "mathematical hypothesis" it becomes a "scientific law". 
therefore I became aware that Celsus' statement was right".

According to Galen the "vitreous humour" was the primary organ of sight prepared by Nature just for this task. By contrast Givanni Battista Della Porta's during 1535-1615, studies and observations had succeeded in realizing that the anatomo-physiological model of the eye was just that of the camera obscura ${ }^{52}$ and René des Cartes (Latinized Cartesius) during 1596-1650 in his turn in the Appendix to his "Discours de la méthode" entitled "La dioptrique" confirmed Christopher Scheiner's during 1573-1650 observation ${ }^{53}$ concerning the upside-down retinal imagine and his explanation of the phenomenon of adjustment ${ }^{54}$.

The Milanese charlatan Giuseppe Francesco Borri (1627-1695) surely knew the treatises of all these authors as he himself states in his "Lettere scientifiche, chimiche e curiosissime" (Most curious Scientific and Chemical letters), which form his treatise "La chiave del gabinetto del Cavagliere Giuseppe Francesco Borri Milanese" (The key of the laboratory of the Milanese Knight Giusepe Francesco Borri). However he still believed in the miraculous virtue of celandine for the regeneration of the "vitreous humours" and devised a no less miraculous device - called by him "medicated water" - which excited both Ole Borch's (1626$1690)^{55}$ and Thomas Barholin's (1616-1680) admiration ${ }^{56}$ during Borri's long stay in Copenhagen at the court of King Frederic III during 1604-1670.

Obviously the boasted miraculous "medicated water" was nothing but a pack of lies as proved by Giovanni Guglielmo Riva during 1627-1677, who - at the presence in his house in Rome of some of his friends and also of the owner himself of the boasted "secret" of the "medicated water" - showed that the same result could also be obtained having recourse to the water of his fountain instead of the mysterious preparation of Borri! Out of mere, the "great revelation" of the "secret" was the following: "You must put a certain amount of purest virgin earth mixed with a 5\% of flowers of sulphur and sow some celandine seeds into an iron vase. This done keep the vase opencast until little plants sprout. At the moment of New Moon, pluck a half of them, roots and loam included, without any a washing ... put them into a glass cucurbit...and add a great amount of celandine powder after having let it dray in the sun a whole day long". Then one must put the dried mixture into an alembic and let it ferment for seven weeks, after which he must "extract the water, which is provided with miraculous virtues". Having the "medicated water" at his

${ }^{52}$ The parallel was already hypothesized by Leonardo da Vinci (1452-1519) although quite uselessly because he never published any of his "Quaderni anatomici" (Anatomical quaternions) that were only discovered at the end of the $19^{\text {th }}$ century!

${ }^{53} \mathrm{Cf}$. His treatise entitled "Rosa Ursina" (printed in Bracciano in 1626-1639) dedicated to Prince Paul Hieronymus Orsini (1591-1656).

${ }^{54} \mathrm{Cf}$. L. Belloni, I/ ciarlatano F. G. Borri (1627-1693) e la rigenerazione degli umori oculari, in Simposi Clinici Ciba, 2; 4, Octtober-November-December, 1965, pages XLIX-LVI. Cf. also A. Corsini, Medici ciarlatani e ciarlatani medici (Charlatan physicians and physician charlatans), Nicola Zanichelli, Bologna, 1922, pages 81-82 and L. Belloni in Storia di Milano (History of Milan), Treccani, Milan, 1958, XI p. $643 \mathrm{ff}$.

${ }^{55}$ Who calls him "a man of noble spirit, of divine memory and provided with an exceptionally competent mind in the field of the chemical mysteries".

${ }^{56}$ To the point that just Bartholin was the editor of the "Two Francesco Borri's letters "On the origin and the medical use of the brain" and "On the device for the regeneration of the eye's humours". disposal, Borri pierced the eye, emptied all the humours, cleaned the cavity with a little brush inserted through the thinnest conic tube used to empty the eye and finally filled the eyeball with his "medicated water" (Figures 8 - 10).

Apart from Greek and Roman vegetal graftings, Branca' and Vianeo's and Indian nose reconstruction and also apart from Borri's

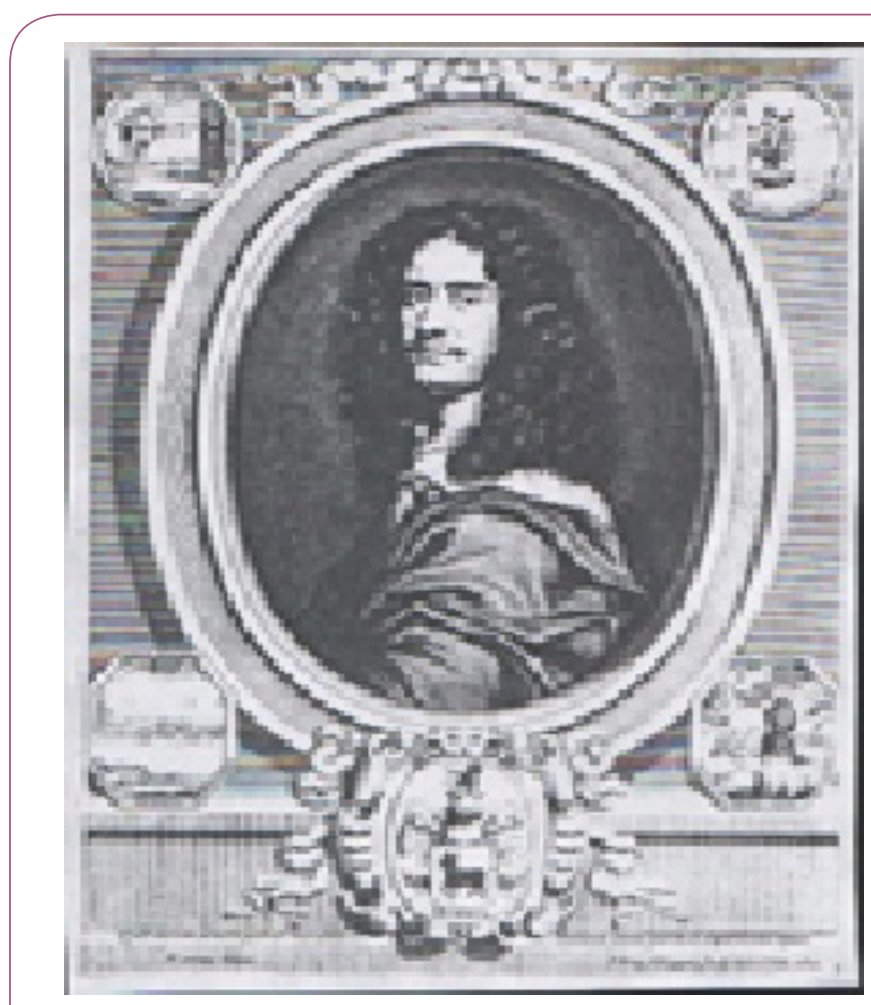

Figure 8 Borri's portrait.

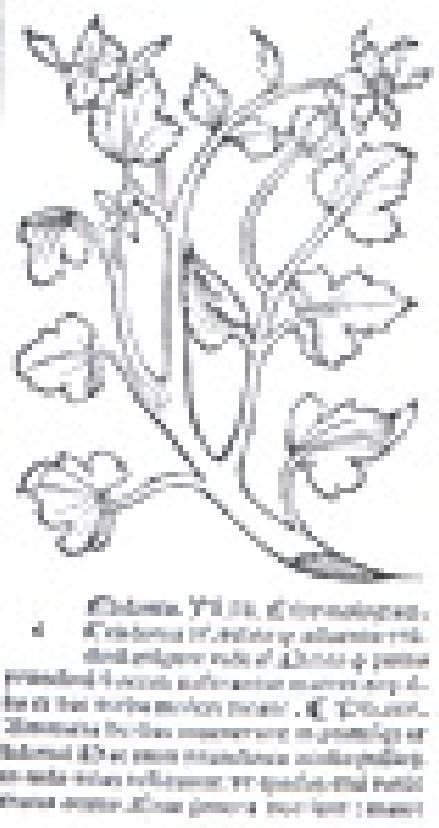

Figure 9 The celandine. 
quackery, at last we can begin dealing with the first real attempts at human transplantations (homografts as well as heterografts) starting from the great English surgeon John Hunter during 17281793, who succeeded in performing teeth transplantations. His method is perfectly described by the Italian surgeon Giuseppe Baronio just at the beginning of the $3^{\text {rd }}$ chapter $^{57}$ of his brief (only but most important treatise "Sugli innesti animali" (On animal graftings), printed in Milan in 1804. The description reads as follows: "The analogous operation to reconstruction of the nose, but much surer and commonly known is the grafting of teeth that aims to usefulness and trimness devised and performed by the renowned Sir John Hunter during 1728-1793, to whom Surgery owes many of its improvements...The grafting of teeth from a person onto another may be performed-according to the English surgeon - without great difficulty but only when the tooth to be grafted is still fresh and provided with a root fit for the receiving alveolus, i.e., neither shorter, nor longer nor bigger". Should the root be either longer or bigger the surgeon must modify it by filing. The grafted tooth root sets perfectly. However the surgeon must be so prudent as to ascertain that the donor doesn't suffer from any disease. At any rate this operation is caused by the fact that "the English ladies were ashamed to attend meetings with some missing teeth". No doubt this is the first case of real "heterograft" only performed for "aesthetic purposes".

But Baronio did not confine himself to dealing with Hunter's reconstructive surgery, but also made a lot of personal and astonishing experiments of both "homograft" and "heterograft" to the point that he succeeded in grafting the wing of a canarybird onto the comb of a cock and even the tail of a cat on the head of cock! Moreover, after having dealt with the Indian surgical procedure for the reconstruction of noses, he made and described three successful experiments of "autograft" by grafting different flaps of ram skin onto the ram itself and illustrated his experiments with a very interesting plate (Figure 11).

The captions of which read as follows:

"First experiment: $a$ ) right side of the graft; $b$ ) left side.

Second experiment: $c$ ) left graft; $d$ ) right graft.

Third experiment: e) right graft; e); f) left graft.

No doubt the brief (only 79 pages!) treatise of Baronio an the previous really astonishing discoveries of his great master Lazzaro Spallanzani (1729-1799) ${ }^{58}$ paved the way for the final revival of plastic and aesthetic surgery starting from 1816 with the English Joseph Constantine Carpue (1764-1846) - who renewed and improved the Indian rhinoplasty technique in $1816^{59}$; with Ferdinand von Graefe (1787-1840) - who devised the surgical procedure for the elimination of congenital cleft palate and was a real pioneer in surgery of the eyelids, of the eye muscles and the jawbones - and with Johann Friederich Dieffenbach during ${ }^{57}$ Entitled "On the grafting of teeth onto a man".

${ }^{58}$ Cf. note n. 34.

${ }^{59} \mathrm{Cf}$. his paper "An Acount of two Successful Operations for restoring a Lost Nose" (1816). Carpue's work revenged, at least in part, the contemptuous silence that accompanied - about one century before - the same procedure devised by René-Jacques-Croissante de Garengeot (1688-1759).
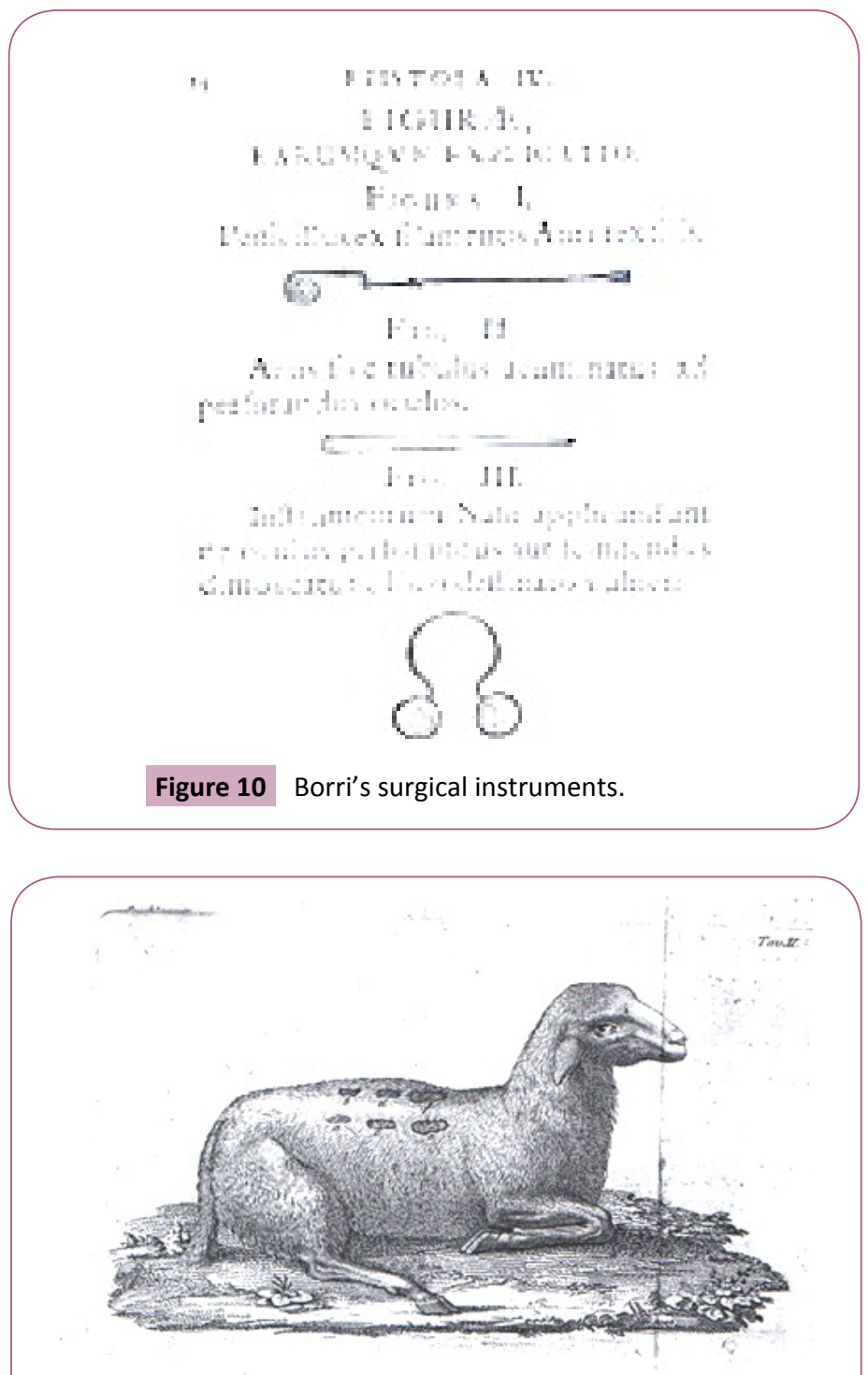

Figure 11 Baronio's experiments: $1^{\text {st }}, 2^{\text {nd }}$ and $3^{\text {rd }}$ from left.

1792-1847, who inaugurated in 1839 the surgical procedure for the elimination of all kinds of strabismus, which was improved and perfected by von Graefe in 1853.

However it is worth remembering that other most important attempts at heterograft (i.e., transfusion against phlebotomy: blood, as everyone knows, is a "tissue") had been already performed in the $17^{\text {th }} / 18^{\text {th }}$ century by Lower R during $1631-1691$, Wren $\mathrm{CH}$ during 1632-1723 and Matthäus Gottfried Purmann during 1648-1711 (Figure 12). Obviously these attempts failed owing to the still general ignorance of blood groups and $\mathrm{Rh}$ factor that will be only discovered by Karl Landsteiner and his collaborators in 1901 and 1940 respectively

All Religions consider work, disease, aging and death as the result of either an original sin, or an original mistake ${ }^{60}$. Hence the

${ }^{60}$ According to the Afrcan Bantu people these terrible damages were caused by an "original mistake": the Gods charged the heavenly here and the heavenly turtle to bring to the men eternal life and death respectively. The hen reached the Moon in one away and seeing that the turtle was still far-off, decided to take a nap. By contrast the turtle went on walking. When, at last, the hen woke, in spite of an as fast as possible 


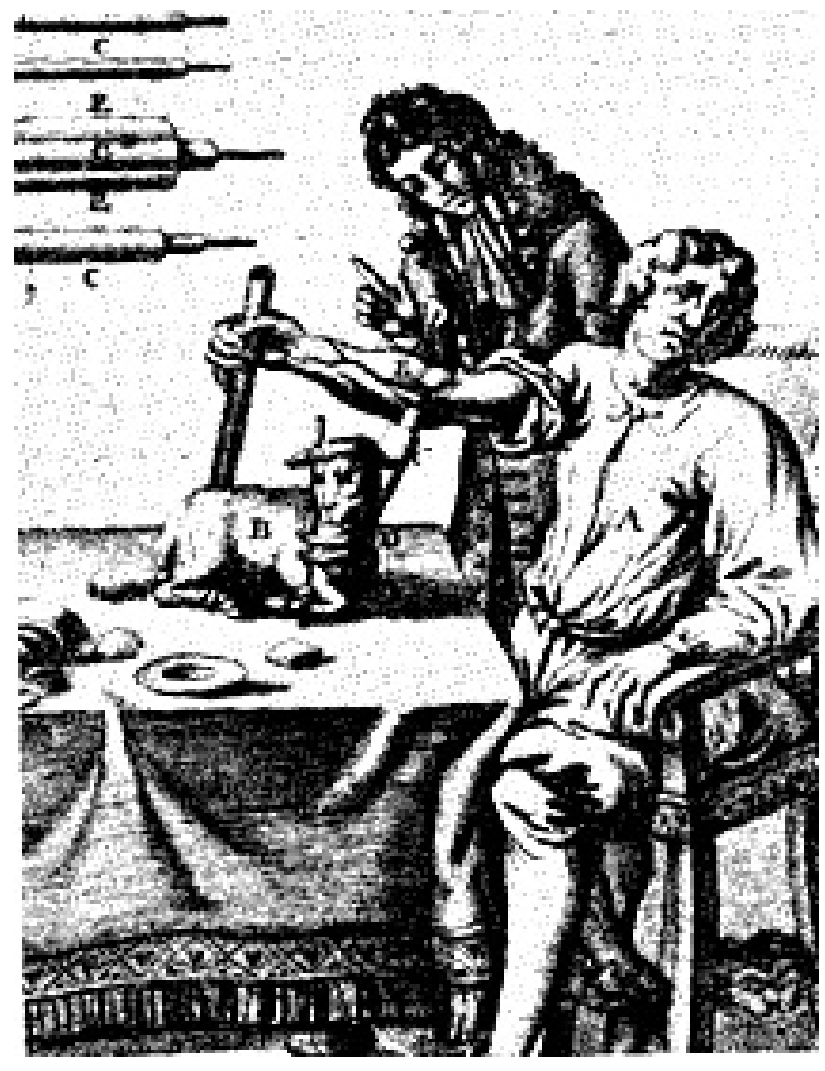

Figure 12 The first illustration of a blood transfusion from a sheep to a man performed by the German surgeon Matthäus Gottfried Purmann (1648-1711) in 1668.

mirage of regaining youth always joined with sex: "Which could ever be life without the Golden Aphrodite? May I be dead as soon as I cannot enjoy ay more furtive sexual intercourse, the sweet pleasures of the bed, which are the delectable fruits of youth!", the Greek poet Mimnermus ( $7^{\text {th }}$ century B.C.) sang ${ }^{61}$ and, in spite of the efforts of Philosophers and Thinkers, abhorring senility and death went on torturing men and forcing them to look frenetically for the phantom "elixir of life" and "of eternal youth". However four causes transferred the vain research of the two "elixirs" from alchemistical ranting to modern "science":

1) The discovery of blood circulation by William Harvey during 1578-1657;

2) The discovery of both "animal reproductions" and "animal graftings" and the consequent "transplantations";

3) The revolutionary discovery of "biological evolution" by Charles Darwin during 1809-1882;

4) The discovery of the endocrine glands and the ever increasing studies of the secreted substances, of their mechanisms and of their functions.

Let us now begin dealing with the first experiments of transplantation of testicles performed by Paolo Mantegazza

run, it was too late: the turtle had already brought to the men the death, thanks to hen's mistake!

${ }^{61} \mathrm{Cf}$. Fragment n. 1. during 1831-1910. He too - like Spallanzani had done his revolutionary experiments of "animal reproduction" in animals with cold blood - performed his experiments of "transplantation of testicles" in frogs and recorded his astonishing results in two really excellent scientific papers ${ }^{62}$, of which he gave a particularly interesting summary in a third paper ${ }^{63}$.

On such a fertile soil Charles Darwin's during 1809-1882, bomb - so to say - exploded: the "Evolution theory", which he advocated in two fundamental treatises: "The origin of species by means of natural selection" in 1859 and "The descent of man" in 1871. We do not think it necessary dealing here with Darwin's "Evolution theory" and mainly confine ourselves to emphasizing the revolutionary statement that man does not derive from monkeys but from the same stem, from which - thanks to "natural selection" - also anthropomorphic monkeys derive, so that the great biologist Thomas Huxley in 1825-1895 - surnamed "Darwin's mastiff" - went as far as to say that man is nothing but a "genial monkey", authorizing - so to say - Serge Voronoff in 1866-1951 to ask himself: "could not the monkeys be considered as primitive men?" and to add: "At any rate the affinity between our tissues and our blood and those of the anthropomorphic monkeys is such that grafting a monkey organ onto a man may be considered the same of grafting an organ of a man onto another man".

"Man rises up against death like against the greatest of all injustices" Voronoff writes just at the beginning of the Preface to his treatise "Vivre, Étude des moyens de relever l'énergie vitale" (Paris, Grasset Éditeur, 1920) ${ }^{64}$ and points out that "the battle between the vital instinct and the horror of death ... always spurred excited the passionate pursuit of the elixir, which may let us extend our life till the moment when satiety of a long life forces us to invoke sleep and rest. However all the attempts failed". In spite of all failures "The experiments made in our laboratory let us hope that this goal may be reached by grafting some glands, which pour into our organism a liquid that stimulates the vitality of our tissues and keeps their resistance against the causes of every wear and tear". Relying on these fundamentals he devised and began performing grafts of monkey testicles onto men and described and illustrated the whole procedure in two treatises ${ }^{65}$.

${ }^{62} \mathrm{Cf}$. Parte Prima. Dell'influenza di alcuni agenti fisici e chimici sui zoospermi della rana, (First part. On the influence of some physical and chemical agents on the frog's zoosperms) in Gazzetta Medica Italiana - Lombardia (Medical Italian Gazette Lombardy), 5 d. s. IV (1860), pp. 215-217 and Parte Seconda. Del trapiantamento dei testicoli da una rana all'altra (Second part. On the transplantation of testicle from one to another frog), ibid. p. $221 \mathrm{ff}$.-

${ }^{63} \mathrm{Cf}$. Atti del Regiolstituto Lombardo di Scinze Lettere ed Arti (Royal Lombard Institute of Sciences, Letters and Arts), 2 (1860), pages 97-98.

${ }^{64} \mathrm{From}$ which we have also derived the former quotations

${ }^{65}$ However it is worth emphasizing that he did not graft an entire testicle, but only $1 / 4$ Cf. "Greffe Animale - Applications utilitaires au chepel" (Paris, Gaston DOIN Éditeur, 1925) and "La Durée de la Greffe des des Glandes endocrines" (Paris, Gaston DOIN Éditeur, 1948). All the quotations derive from these two treatises. Cf also the brief but excellent article: S. Musitelli, D. Schultheiss, J. Denil, U. Jonas Androgen therapy and rejuvenation in the early 20th century, in De Historia Urologiae Europaeae, 6 ${ }^{\circ}$, Groeninge Drukkerij, Kortrijk, 1999, p. 143 ff. See the attached figures n.10 and n. 11.

Cf. S. Musitelli, "Welcome born-again Dr. Faust" in "The aging male", 2004; 7: 179183 
Moreover he did not confine himself to performing transplantations of testicles, and giving his patients a more or less illusory and more or less lasting "rejuvenation", but also practised successfully and illustrated cases of "aesthetic surgery": "Even the skin - e writes - may be replaced without great difficulty by either taking it from a bare zone of the body of the patient himself, or having recourse to foetal membranes... as I had the occasion of doing onto a young woman, who had her face and her ands horribly burnt" and showed his exceptional results with two very interesting photos (Figures 13 and 14).

However let us quote two other exceptionally interesting passages dealing with "aesthetic surgery. The first reads as follows: "Even replacing an artery is not at all difficult...In this case one must remove some arteries from a recently dead person and keep them in an ice-box in order to have them at our disposition in due time"; in the second he records the successful replacement of an entire knee joint "with the same joint I had removed from a dead patient and preserved into an ice-box for 24 hours"; the third reads as follows: "As the monkey can provide men with vital energy, it will be considered to be the most precious of all animals" to obtain "rejuvenation".

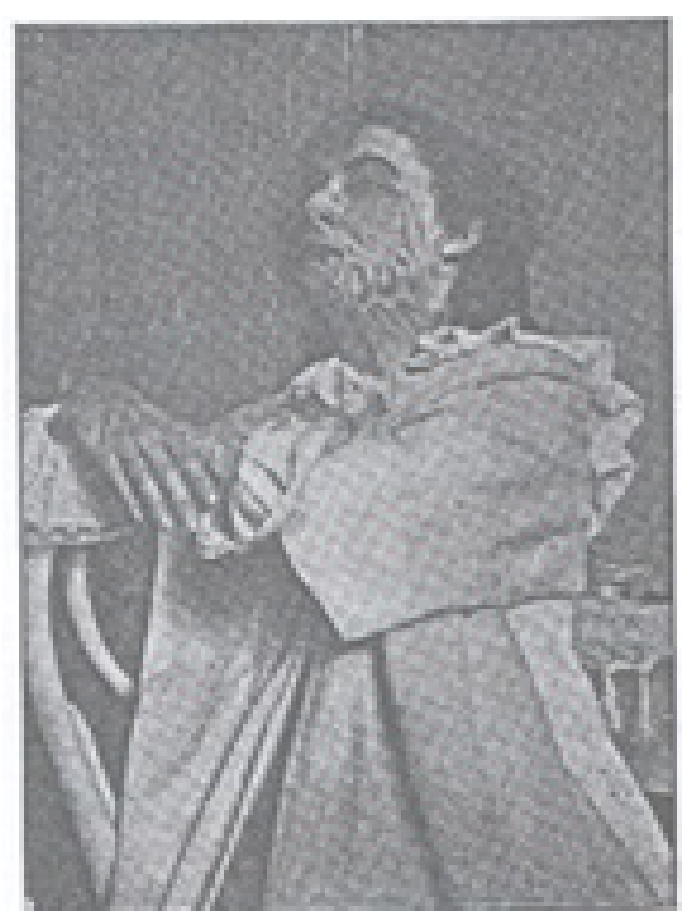

Figure 13 The patient before the operation.

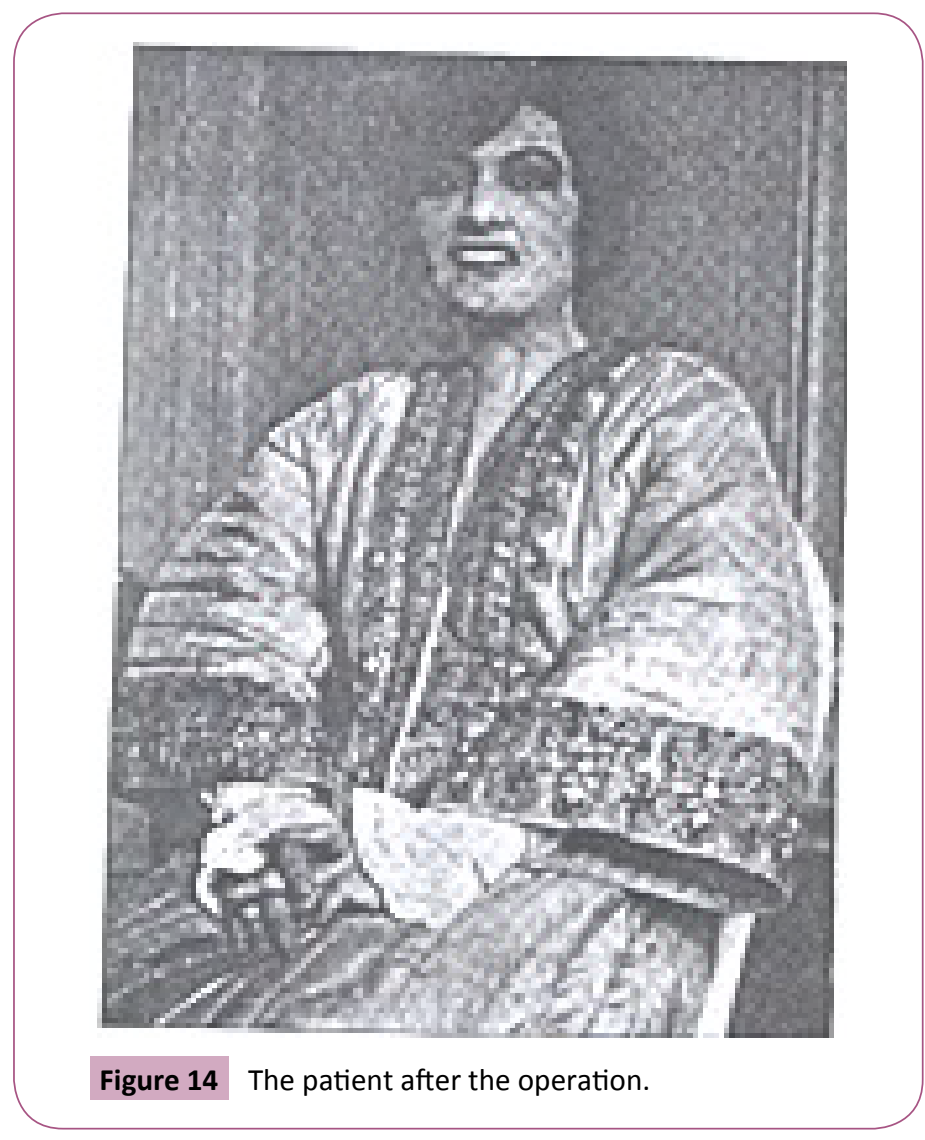

\section{Conclusion}

We can affirm that Voronoff ${ }^{66}$ from the one hand revived Dr. Faust's myth ${ }^{67}$; from the other hand started not only the astonishing achievements of modern "plastic and aesthetic surgery", but also - and unfortunately! - The exceptional spread of more or less efficient and - to tell the truth - generally absolutely ineffective and charlatanic, but always highly profitable - "rejuvenation" means ${ }^{68}$ and of the no less profitable but exceptionally boasting as well as quack "Anti-aging Societies" and "Anti-aging Associations".

\section{Acknowledgements}

My sincere thanks to Mr. Oddenino and I also dedicate this work to the memory of my adored son Giulio, who was killed on May 14, 2012 by a criminal driver, who did not observe a STOP sign.

${ }^{66}$ Together with the fundamental studies and discoveries of Eduard Brown-Séquard (1817-1894) and Eugen Steinach (1861-1944)

${ }^{67}$ Cf. S. Musitelli, "Welcome born-again Dr. Faust!" in The aging Male, 2004 $7: 170-183$

${ }^{68}$ Not only anti-wrinkles creams and hyaluronic acid, but also Viagra, Cialis, Sildenafil Stem cells, Lifting, prosthesis for artificial erection of the penis, nutritionists' researches and rules and what have you! 